\title{
Experiences of the National Deposit Insurance Fund on the Age Composition of Depositors and on the Distribution of Deposit Amounts*
}

\author{
Katalin Csaba-Kalló - Balázs Vajai
}

In the span of two years (2014 and 2015), ten credit institutions were liquidated in Hungary. Depositors were reimbursed by the National Deposit Insurance Fund (NDIF) in the total amount of HUF 219 billion. This is the first time that the depositor database of the liquidated credit institutions is subject to research. The basic features of the compensation data are presented with the assistance of descriptive statistics tools in the dimensions of the paid-out compensation amounts and the age of depositors. We confirm the hypothesis that the paid-out compensation amounts follow an extreme value distribution, more specifically, a Weibull distribution. The distribution shows that above HUF 5 million, the number of reimbursed depositors grew only moderately, while the paid-out compensation amounts increased significantly. Moreover, in making a comparison between the age distribution of reimbursed depositors and the age distribution of the Hungarian population we found that the savings deposited with the liquidated credit institutions are consistent with Modigliani's life-cycle hypothesis.

Journal of Economic Literature (JEL) codes: D14, D18, G21

Keywords: household saving/personal finance, consumer protection, banks

\section{Introduction and motivation}

In 2015, the Hungarian household sector held about 20 per cent of its financial assets (HUF 9,000 billion) in bank deposits and bank bonds (Boldizsár - Koroknai 2016). This substantial volume allotted to bank financing underlines the key significance of deposit insurance as a tool for building and maintaining confidence in the banking sector. By strengthening confidence in the banking sector, the existence of the deposit insurance scheme serves as a safeguard for the stability of the financial system. At present, pursuant to the authorisation granted under Act CCXXXVII of

* The views expressed in this paper are those of the author(s) and do not necessarily reflect the offical view of the Magyar Nemzeti Bank.

Katalin Csaba-Kalló is a PhD candidate at Corvinus University of Budapest.

E-mail: csaba.katalin.corvinus@gmail.com.

Balázs Vajai is Chief Risk Officer at the National Deposit Insurance Fund. E-mail: vajaib@oba.hu.

This article presents the authors' views and does not necessarily reflect the official opinion of the National Deposit Insurance Fund.

The manuscript was received on 19 December 2016.

DOI: http://doi.org/10.25201/FER.16.2.2839 
2013 on Credit Institutions and Financial Enterprises (Act on Credit Institutions), the Hungarian deposit insurance scheme is operated by the National Deposit Insurance Fund (NDIF). Within twenty working days, the NDIF pays compensation to depositors both private individuals and legal entities entitled to compensation - if their accounts held at a credit institution are frozen due to the insolvency of the credit institution. Starting from 2011, the NDIF pays compensation in forints up to a maximum amount of EUR 100,000 per depositor and per credit institution on aggregate, whereas it

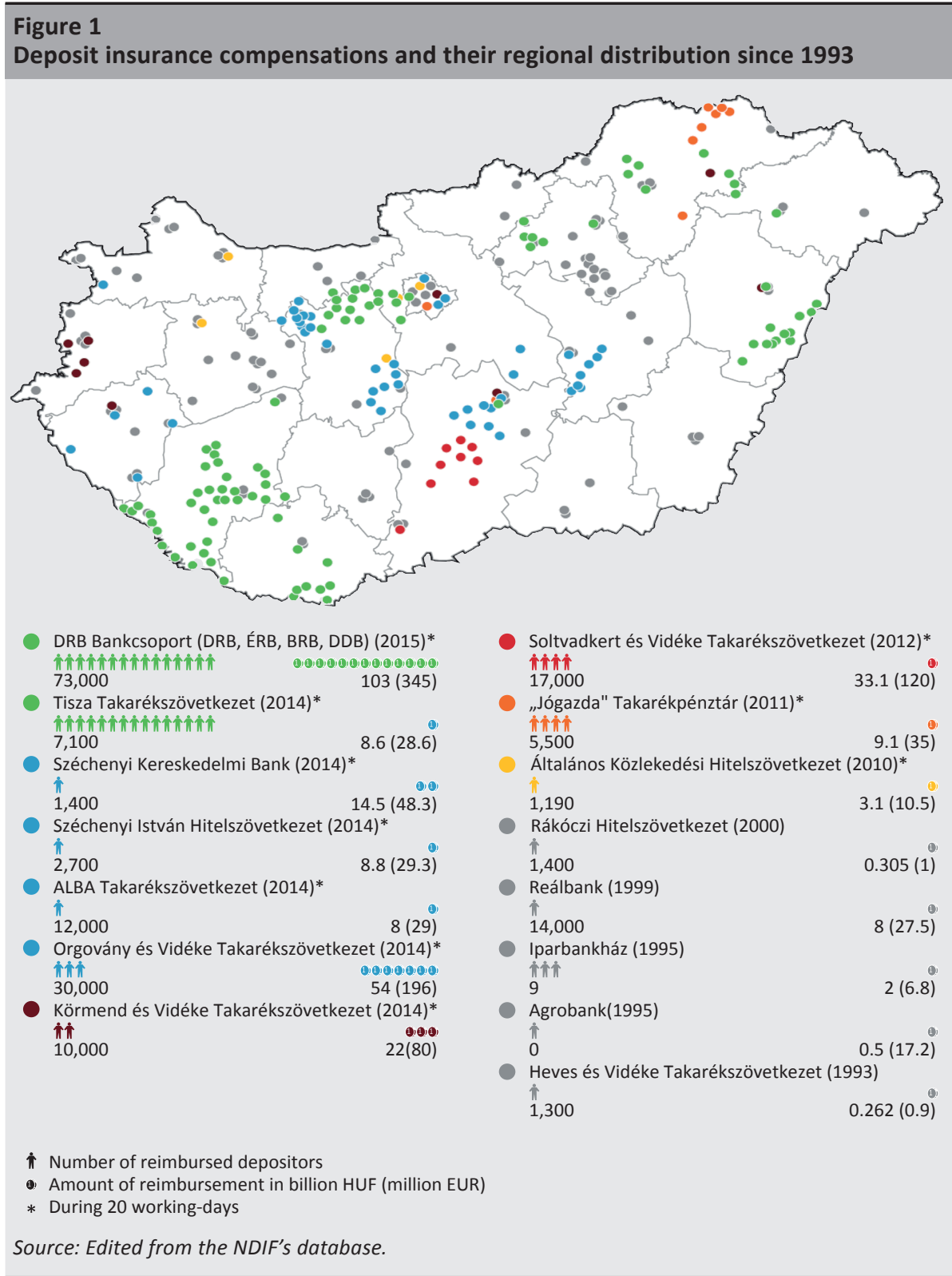


had previously paid the forint equivalent of EUR 50,000 (National Deposit Insurance Fund, 2017). ${ }^{1}$ According to the NDIF's calculations, it has paid HUF 275 billion in compensation to nearly 177,000 customers since its establishment in 1993 (aggregated at nominal value). The locations of the branches of closed down credit institutions in Figure 1 suggest that the liquidations affected depositors nationwide.

As indicated on the map, 18 credit institutions have been liquidated since the foundation of the NDIF. Liquidations were concentrated in the past two years with the closure of 10 credit institutions, of which two institutions generated the largest volume of compensations so far (Orgovány and Region Savings Cooperative and, composed of four banks, the DRB Bank Group ${ }^{2}$ ).

The substantial amounts paid out in compensation in 2014 almost depleted the NDIF's reserves and it was in this financial situation that the NDIF faced the liquidation of the DRB Bank Group in 2015. After entering into a bridging loan agreement with the MNB, the NDIF obtained refinancing through the issue of NDIF bonds within three months. The effect of compensation obligations is illustrated by the changes in the NDIF's coverage ratio in Figure 2. The coverage ratio is an indicator of the asset position, i.e. funding of deposit insurance institutions, which compares the liquid assets of the Deposit Insurance Fund to the theoretical compensation obligation of the Fund at the member institutions at a given time. If a credit institution goes bankrupt, the funds available for the compensation of depositors originate primarily from two sources of

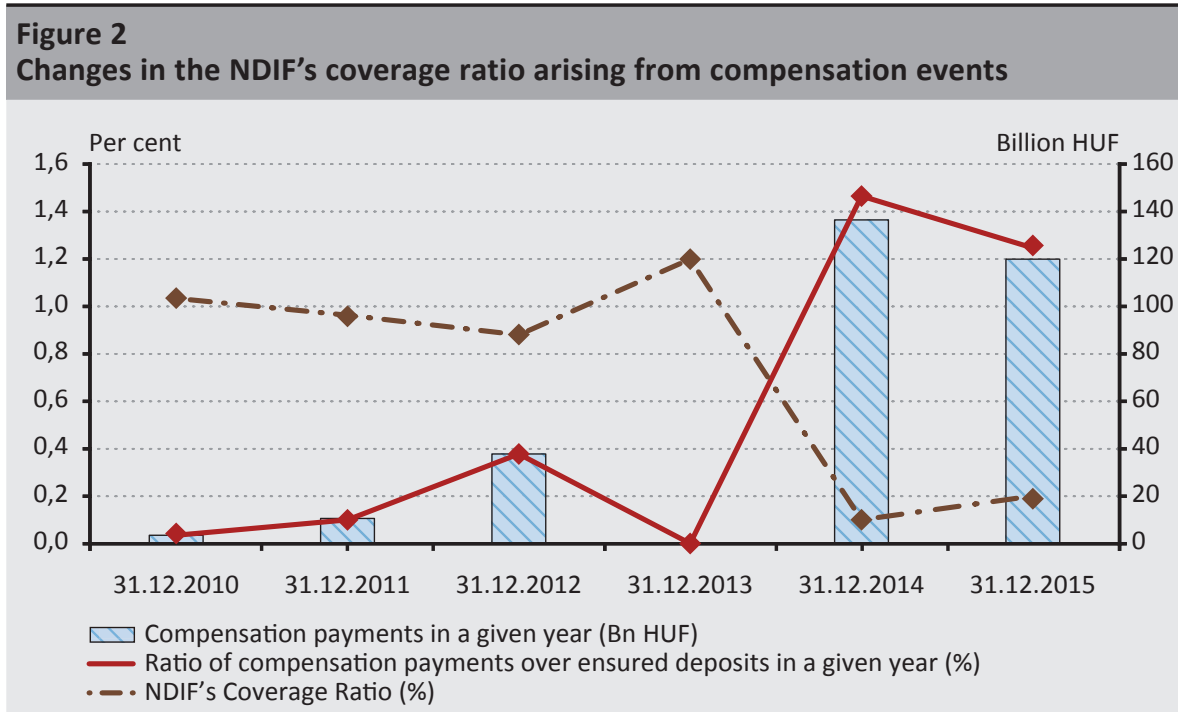

Source: Edited from the NDIF's database.

${ }^{1}$ In exceptional cases, the compensation limit may be increased by an additional amount of up to EUR 50,000. Deposits placed before 1993 remain fully covered by a state guarantee until withdrawn.

2 The four banks comprising the DRB Bank Group are BRB BUDA Regional Bank, DRB Southern Transdanubian Regional Bank, Southern Transdanubian Savings Bank and ÉRB Northern Hungarian Regional Bank. 
revenue: the deposit insurance fees paid by the member institutions in the current year and the proceeds from the return on the investment of the accumulated fees into government securities (NDIF 2016:19).

Until 2013, the coverage ratio of the NDIF was stable and consistently hovered around 1 per cent; by 2014, however, it had fallen to 0.1 per cent and it has remained at this level ever since. With this value, as of 31 December 2015 the NDIF recorded one of the lowest coverage ratios among European deposit insurers. Under European Union regulations, ${ }^{3}$ the coverage ratio of deposit guarantee schemes must reach the 0.8 per cent target level by 3 July 2024. At the current replenishment level of the Fund, reaching the target level and fulfilling the obligations undertaken in relation to the bond issue will require a substantial amount of contribution on the part of member institutions. This is because 1.47 and 1.25 per cent of the NDIF's compensation obligation for the total stock of covered deposits had to be paid out in compensation over the past two years, respectively. It should be noted that the 0.8 per cent minimum target level to be achieved in compliance with the European Union directive would have been insufficient to cover the compensation needs in both years. Therefore, existing compensation experiences should also be considered upon the calculation of the target level as an addendum to the minimum regulatory requirements.

This is the first time in years that the depositor databases of the credit institutions liquidated in Hungary are being analysed for scientific purposes, and the results are presented in this study. The experiences of previous compensations have only been analysed from the perspective of depositors' reactions so far, based on calls received by the NDIF (Kiss 2015).

The findings of this analysis can be utilised for various purposes; for example, they reveal the typical amounts placed by customers in the liquidated institutions and give an insight into the age composition of aggrieved depositors. From this information we can draw conclusions about savings and banking habits. In addition, the distribution of deposit amounts can be used for the calculation of the optimal deposit insurance compensation limit.

\section{Data and methodology}

Of the credit institutions liquidated in Hungary, we analyse the depositor databases of institutions liquidated in 2014 and 2015, which cover 77.1 per cent of all depositors reimbursed since 1993 and 79.5 per cent of the total compensation amount. This study focuses on the analysis of compensations paid out to private individuals in the amount of HUF 188.9 billion, but we also touch on the protection provided to companies (HUF 10.8 billion). The total database also contains the compensation amounts paid on joint accounts ${ }^{4}$ (HUF 0.5 billion), which might be the subject of

\footnotetext{
${ }^{3}$ Article 10(2) of Directive 2014/49/EU of the European Parliament and of the Council

${ }^{4}$ Typically condominiums.
} 
further research. The units of the database comprise compensation amounts by depositor and by credit institution. Accordingly, if a depositor was affected by the liquidation of more than one credit institutions, the compensation associated with the depositor will be shown in more than one row. The NDIF reimbursed depositors up to the compensation limit for all of their accounts and deposits ${ }^{5}$ secured by insurance. The value range of the compensation amount associated with the deposits is the forint equivalent of EUR $0-100,000 .{ }^{6}$ The statistics are compiled by stripping out compensations amounting to 0 . Customers not eligible for compensation typically had outstanding debts or their consolidated account showed a balance of 0 . These items are excluded to ensure that the average compensation amount and its standard deviation remain unbiased. Since the database does not contain the original deposit amount, we have no information on the amount of unreimbursed damages. We will see, however, that relatively speaking, few deposits achieved maximum repayment. Apart from the compensation amounts, the data available on depositors include their date and place of birth and the postal code of their permanent address. This information is suitable for further research; a review of the possibilities and the expansion of the database are in progress.

The database of the depositors of liquidated credit institutions is analysed with descriptive statistics tools in the dimensions of paid-out compensation amounts and the age of depositors. In the first step, we examine the arithmetic mean, the standard deviation and the distribution of the compensation paid. The results of the statistics are also analysed at the institution level, in order to explore potential institution-specific features. In view of the distribution of paid-out compensation, we formulate and then test the hypothesis that the paid-out compensation amounts follow an extreme value distribution, more specifically, a Weibull distribution. We analyse the age distribution of reimbursed depositors in comparison to the age distribution of the Hungarian population. For this, we supplemented the database provided by the NDIF with the relevant demographic data collected from the Hungarian Central Statistical Office (HCSO 2015). The calculations and in part, the graphics, were prepared with the assistance of an $\mathrm{R}$ programme package.

\section{Compensation experiences and conclusions}

\subsection{Descriptive statistics, institution-specific findings}

In the first step, we analyse the depositor database of each liquidated credit institution with respect to the arithmetic mean and standard deviation of the paidout compensation amount. The overall average of the compensation paid out to private individuals and companies is HUF 1.7 million, which is indicated in Figure 3 with a horizontal dotted line. We interpret the statistics of the individual institutions in comparison to the overall average.

${ }^{5}$ Documentary deposits, deposit accounts, current accounts, bank accounts, payment accounts.

${ }^{6}$ Converted at the HUF/EUR exchange rate effective on the day of the reimbursement. 


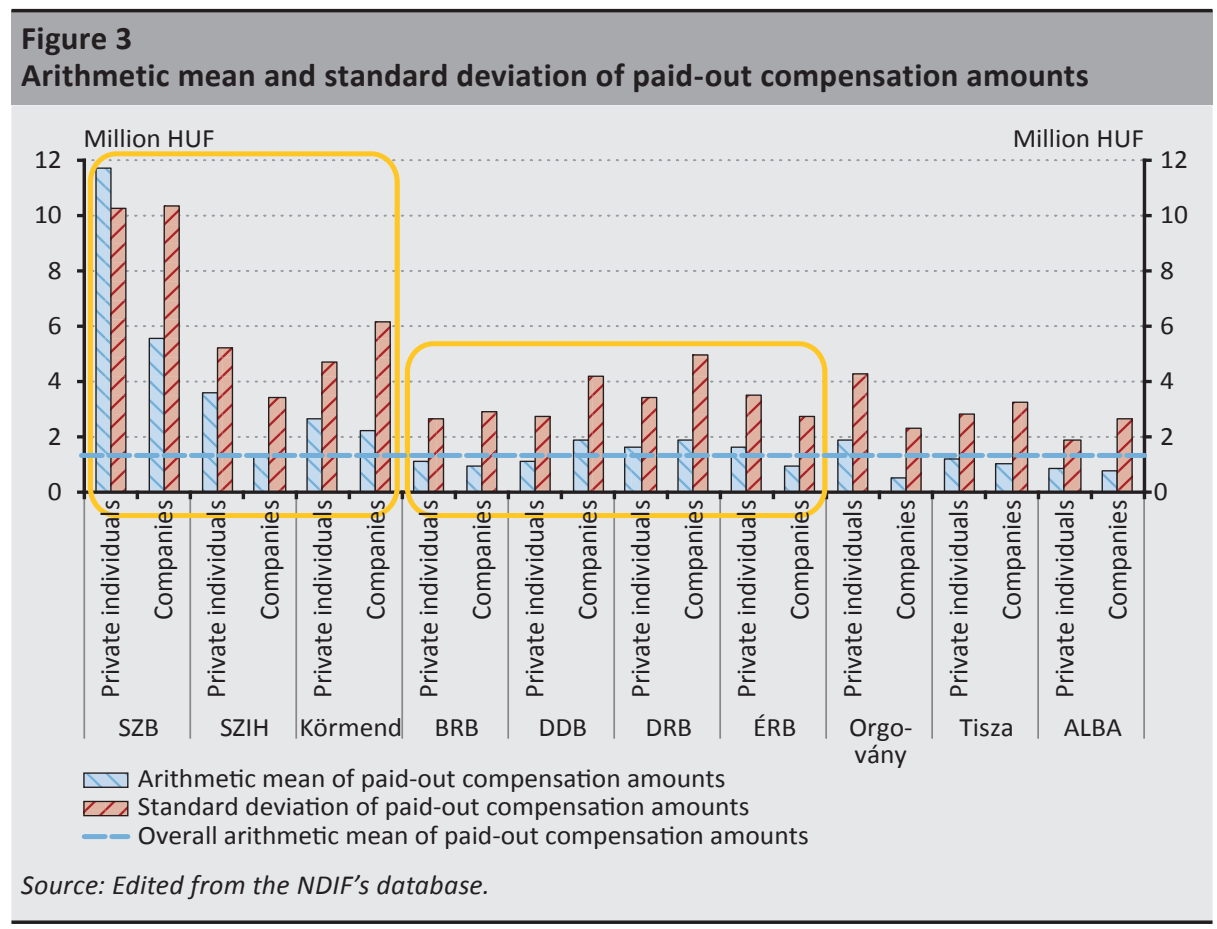

The arithmetic mean is far higher than the overall average at Széchenyi Commercial Bank (SZB), at Széchenyi István Credit Cooperative (SZIH) and at Körmend and Region Savings Cooperative (Körmend). This may be attributed to the fact that these three credit institutions were interests of the same owners; consequently, they may have had coordinated fundraising policies. Presumably for similar reasons, the four institutions of the DRB Bank Group (BRB, DDB, DRB, ÉRB) also exhibit arithmetic means close to one another, distributed around the overall average. The average compensation amount of the remaining three credit institutions typically falls short of the overall average. While this research is not intended to explore the reasons behind the credit institutions' default, it should be pointed out that of the ten liquidated institutions, ownership concentration posed a risk of cross-financing at seven institutions. Therefore, in our view, exploring and monitoring the ownership/interest structure of individual institutions would be advisable from a supervisory perspective.

We may conclude, overall, that the statistics of Széchenyi Commercial Bank deviate from the rest of the credit institutions in several regards. Per deposit, the average amount of compensation is more than seven times the overall average (HUF 11.8 million) for private individuals and more than three times the overall average (HUF 5.5 million) for companies. The Bank's clientele was explicitly dominated by major depositors (private banking segment). At around 200 per cent, the relative deviation was high at all of the institutions except Széchenyi Commercial Bank, where relative deviation was around 90 per cent in the case of private individuals. The statistics of 
Széchenyi Bank diverge from the values of the rest of the institutions even in respect of the distribution of the compensation amounts. While the assumption of normality for the distribution of the compensation amounts can be clearly rejected ${ }^{7}$ at all of the other institutions, the distribution of compensation amounts approximates the normal value at Széchenyi Commercial Bank. Figure 4 (Q-Q plot) illustrates this.

\section{Figure 4 \\ Q-Q plot analysis of the distribution of Széchenyi Bank compensations}

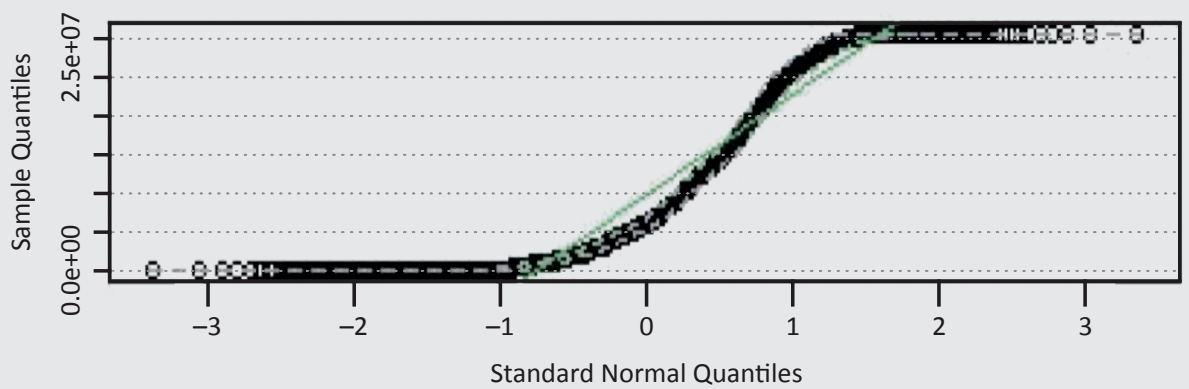

Source: Edited from the NDIF's database.

Since the shapes of the distribution function for each institution except Széchenyi Bank are very similar to one another and to the distribution of all compensations, we present below the analysis of the distribution of the total population.

\subsection{Distribution of compensation amounts}

The distribution of compensation amounts provides insight into the typical amounts deposited at the compensated institutions (Figure 5). The distribution function of the total population is strongly left-skewed (Mode < Median < Mean), and the right tail of the distribution is drawn out along the length of the horizontal axis. There are no outliers; therefore, in Figure 5 we present only the left edge of the distribution function graphically, indicating the decile values describing the entire distribution. The most frequently observed, typical compensation amount (mode, i.e. the maximum value of the function) is only around HUF 100,000. The median is also low: HUF 368,000; in other words, for half of the deposits the compensation was less and for the other half of the deposits it was more than this amount. The arithmetic mean of the compensation amount is HUF 1.7 million per deposit, even higher than the seventh decile. Therefore, the shape of the distribution function indicates that typically, a higher number of loweramount compensations were paid out. This may be because the deposit insurance covers not only deposits with an agreed maturity, but also current accounts where - in the lack of an agreed maturity - typically smaller amounts are held.

${ }^{7}$ Based on the Kolmogorov-Smirnov test. In all nine cases, the mean was far higher than the average; in fact, it exceeded even the third quartile in eight cases. The distribution, therefore, was left-skewed compared to a normal distribution at all nine institutions. The analysis covered both private individuals and companies. 


\section{Figure 5}

Part of the distribution function of the compensation amounts and its decile values

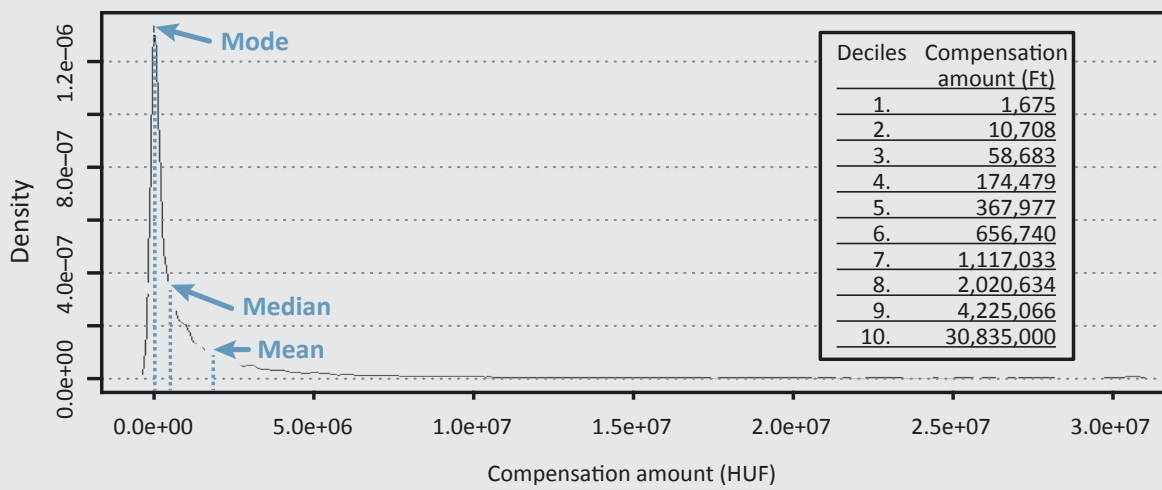

Source: Edited from the NDIF's database.

The decile values of the distribution also indicate that even with a maximum compensation amount of HUF 4.2 million (9th decile) only, 90 per cent of the deposits could have been reimbursed. The fact that the distribution is rightskewed and peaked ${ }^{8}$ suggests that the assumption of normality can be rejected. This conclusion was also confirmed by the Q-Q plot analysis.

\section{Figure 6}

Normality testing with Q-Q plot analysis

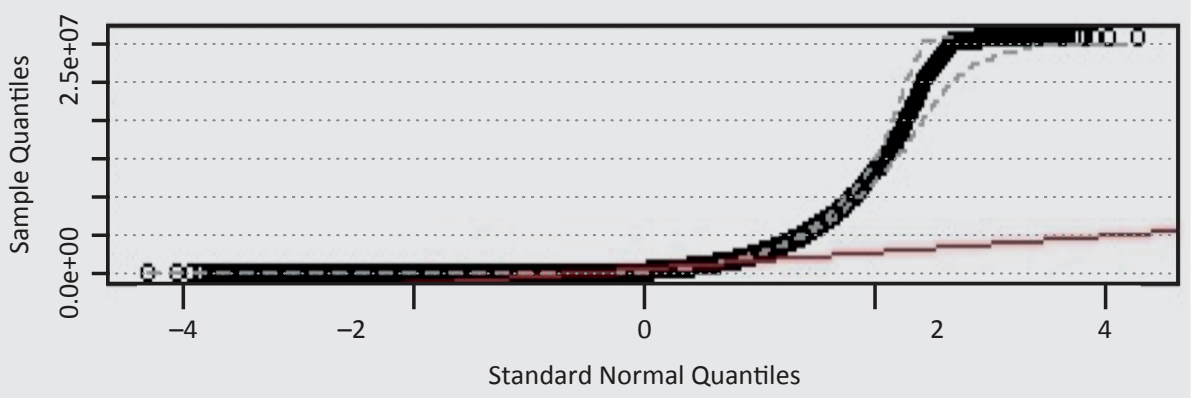

Source: Edited from the NDIF's database.

Based on the graphical representation of the distribution function, we formulate the hypothesis that the compensation amounts follow an extreme value distribution, more specifically, a Weibull distribution.

${ }^{8}$ The K-indicator - a measure of peakedness - stands at 0.175 , which describes a more peaked distribution than the normal distribution (0.263). 
If $x>0, k>0, \lambda>0$, the distribution function of the Weibull distribution can be written as:

$$
F(x ; k, \lambda)=1-e^{-(x / \lambda)^{k}}
$$

where:

$k$ is the shape parameter; its estimated value, in this case is: $k(0.44)$

$\lambda$ is the scale parameter; its estimated value, in this case is: $\lambda(696,305)$

The $k<1$ value of the shape parameter indicates that the distribution is drawn out to the right; in other words, the frequency of payments strongly decreases towards higher compensation amounts. Accordingly, a potential increase in the compensation limit would significantly raise the compensation amount, but barely increase the number of depositors.

We tested the hypothesis by comparing the empirical and the theoretical distribution; the results are shown in Figure 7.

\section{Figure 7}

Testing the Weibull distribution
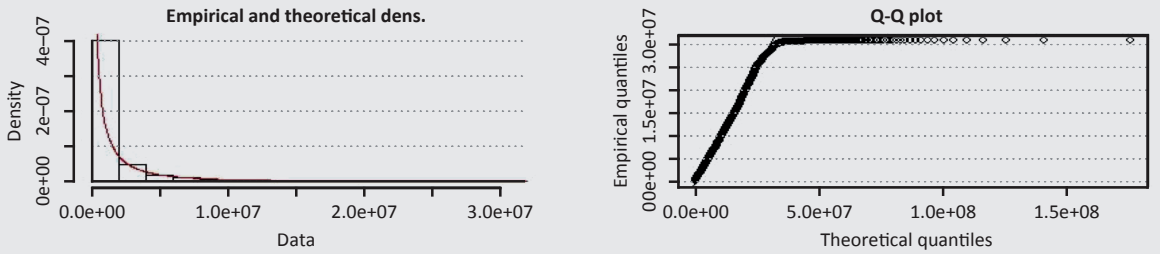

Empirical and theoretical CDFs

P-P plot
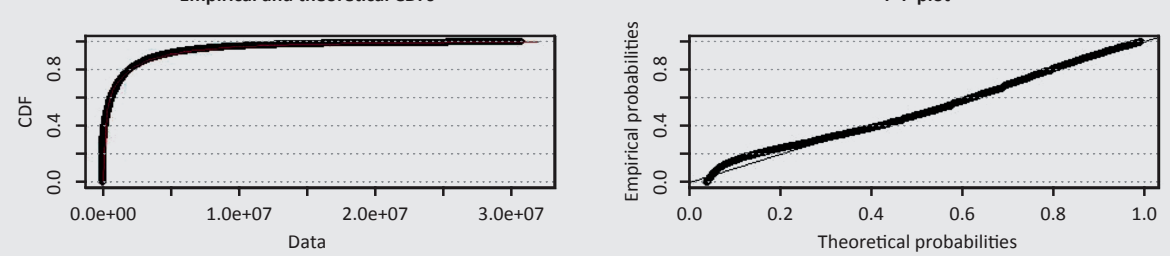

Source: Edited from the NDIF's database.

The empirical distribution of the compensation amounts shows that above HUF

5 million, the number of reimbursed depositors grew only moderately, while the paid-out compensation amounts increased significantly. 


\subsection{Conclusions based on the distribution of compensation amounts}

Based on the analysis of the distribution of compensation amounts, we can expect the conclusion that from a deposit insurance perspective, the optimal deposit insurance protection limit is far lower in Hungary than the amount currently required by the European Union (EUR 100,000). This view is supported by the information available on the distribution of the deposit amounts of operating banks: it shows that at the end of 2015, the insured deposit amounted to less than HUF 5 million in the case of 97 per cent of the private deposit accounts covered by the NDIF. ${ }^{9}$ Therefore, with a potential reduction of the protection limit to HUF 5 million, except for 3 per cent, the deposits of all currently insured private individuals would remain guaranteed, while the insured deposit portfolio would decline by HUF 2,426 billion, which represented 42 per cent of the total insured deposit portfolio of private individuals at the end of 2015. ${ }^{10}$

In summary, at first sight, a drastic decline in the insured deposit portfolio would render the deposit guarantee scheme cheaper as the insured deposit portfolio would require a far lower level of reserves and consequently, the fee payable to the deposit insurer would also decline. At the same time, however, there is a need to model the behaviour of smaller depositors dropping out of the deposit guarantee scheme. Indeed, the reduction of the protection limit may lead to a confidence crisis and massive deposit withdrawals, which would jeopardise the stability of the financial system. The definition of an optimal deposit insurance protection limit would be mainly driven by the aforementioned factors. The quantification of such an optimal value is outside of the scope of this study and should be the subject of further research.

\subsection{Age composition of reimbursed depositors}

We also analysed compensation data in the dimension of depositor ages. With respect to the mean and deviation of the ages of reimbursed depositors, there are no significant differences between the credit institutions. The average age of depositors ranges between 52 and 60, while the deviation varies between 15 and 21 years. The high standard deviation may be partly attributed to the fact that current account and current account related products (overdraft facilities, debit cards, credit cards, etc.) are used by all age groups.

We analysed the age distribution of reimbursed depositors in comparison to the age distribution of the Hungarian population in such a manner that the same chart shows the ratio of reimbursed depositors by age to all reimbursed depositors and the ratio of the population by age to the total Hungarian population (Figure 8).

\footnotetext{
${ }^{9}$ Calculated from the NDIF's database.

${ }^{10}$ Calculated from the NDIF's database.
} 


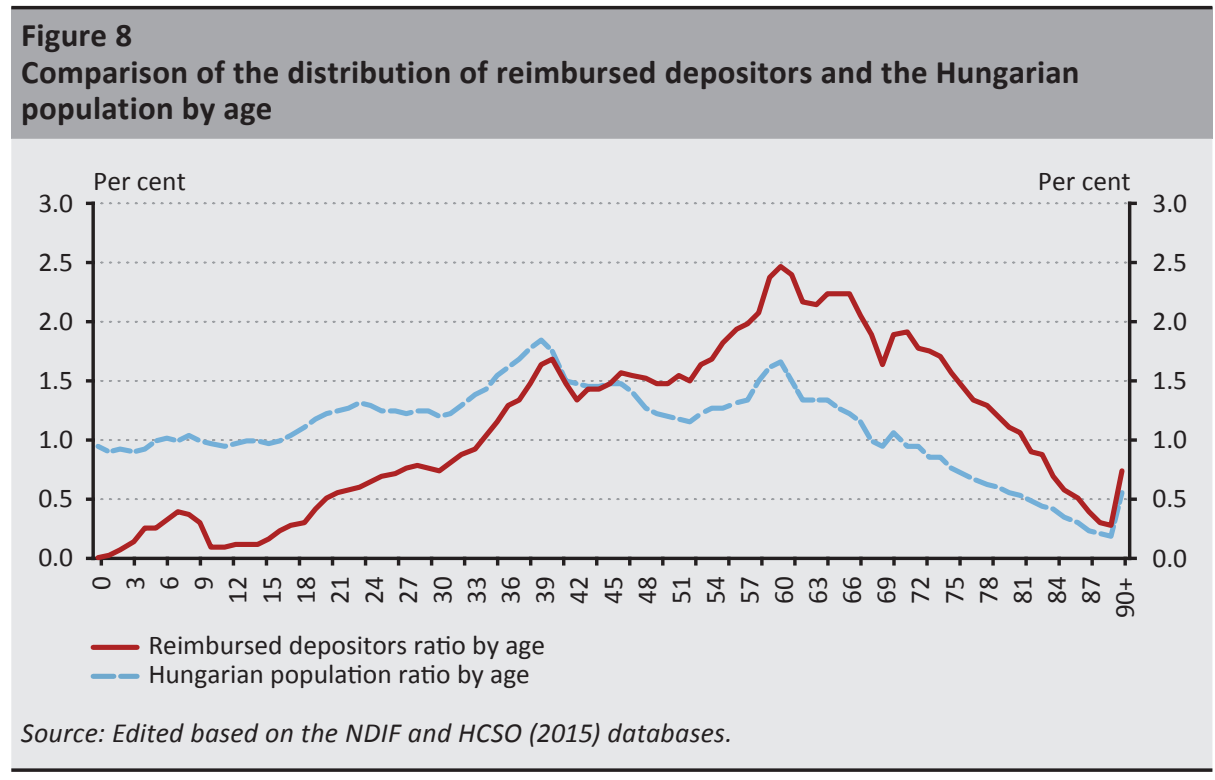

As shown in Figure 8, it is only in the case of age groups $40-45$ and above 90 years that the two curves are aligned with one another. On the whole, therefore, the depositors of the liquidated credit institutions do not represent the demographic distribution of the Hungarian population. The ratio of young persons with deposit and current account products in the liquidated credit institutions is far lower than their ratio to the total population by age. At around 1.5 per cent, the two ratios are roughly identical in the age group of 40-45. The proportion of those above 45 years of age within the depositors is higher than would have been warranted by their ratio to the total population. The ratio of depositors by age peaks at 60 years of age (2.5 per cent), which is one per cent higher than the ratio of the 60 -year-old population to the total population. As the ages increase, the curve of reimbursed depositors approximates that of the total population from above and the two curves overlap at the age group of 88 and above. The comparison of the proportion of reimbursed depositors and the Hungarian population by age group also reveals that the curve of reimbursed depositors tracks the demographic jumps of the Hungarian population („Ratkó children” and „Ratkó grandchildren"). Consequently, banks may conclude from our analysis that they should use demographic trends as a baseline in the evaluation of their portfolios.

In addition, the positioning of the two curves relative to each other suggests that the number of accounts and deposits placed in the liquidated credit institutions is consistent with Modigliani's life-cycle hypothesis (Modigliani, 1986). Modigliani's life-cycle hypothesis is one of the basic models applied in the research exploring households' propensity to save. According to the hypothesis, households make rational decisions about their consumption patterns over their different life-cycles, and adjust their savings behaviour to these decisions. The savings rate of young 
households is either low or negative (they are more likely to borrow funds) as their relatively low income is coupled with high expenditures (housing, childrearing). Later on in the medium stage of their life cycle households with higher income allocate a larger portion of their income to savings in order to save up for their post-retirement lives when, according to the basic assumption of the model, their income drops down to zero (Modigliani, 1988). It should be the subject of further research whether the distribution of average compensation amounts by age supports Modigliani's life-cycle hypothesis empirically.

\subsection{Conclusions based on the age composition of reimbursed depositors}

In summary, the analysis of the age composition of reimbursed depositors suggests that, in line with Modigliani's life-cycle hypothesis, ages below 40 - including, in particular, young adults and minors - are under-represented in the portfolio of new deposits relative to their ratio to the total population. From the banks' perspective, this result might be an indication that designing products targeting the young generation has significant potential. Consequently, even banks have a vested interest in promoting financial literacy and incorporating bank account management into the education system.

\section{References}

Boldizsár, A. - Koroknai, P. (2016): Nem is gondolnád, mi mindent tettek félre a magyarok (2. rész) (Changes in the composition of the savings of Hungarian households, Part 2). Online: https://www.mnb.hu/letoltes/boldizsar-anna.pdf. Downloaded: 29 November 2016.

Kiss, H.J. (2015): Nem pánikoltuk túl a brókercsődöket (Moderate anxiety over broker defaults). Online: http://index.hu/gazdasag/penzbeszel/2015/03/23/oba_bank_bankbetet. Downloaded: 1 December 2016.

HCSO (2015): Hungarian Central Statistical Office: Népesség korév és nem szerint (Population by age and sex). Online: http://www.ksh.hu/docs/hun/xstadat/xstadat_eves/i_wdsd009. html. Downloaded: 10 November 2016.

Modigliani, F. (1986): Life cycle, individual thrift, and the wealth of nations. American Economic Review, Vol. 76, pp. 297-313.

Modigliani, F. (1988): Pénz, megtakarítás, stabilizáció (Money, savings, stabilisation). Közgazdasági és Jogi Könyvkiadó, Budapest.

NDIF (2017): National Deposit Insurance Fund: Deposit insurance. Online: http://oba.hu/ en/deposit-insurance. Downloaded: 29 March 2017.

NDIF (2016): National Deposit Insurance Fund: NDIF Annual Report 2015. Budapest, 22 May 2016, p. 19. 